\title{
[Review] \\ A Conceptual Framework for Determination of Appropriate Business Model in e-Learning Industry in Iran
}

\author{
Abbas Salehinejad*, Reza Samizadeh ${ }^{* *}$ \\ Received: August 14, 2016. Revised: April 29, 2017. Accepted: July 15, 2017.
}

\section{Abstract}

Purpose - The purpose of this study is to present a framework for determining the most appropriate business model for e-learning.

Research design, data, and methodology - The Electronics Branch of Azad University has been elected as a case study in this research. This study conducted using a descriptive method. The information was obtained using interviews with experts including managers, faculty and students at the Electronics Branch of Azad University.

Results - Three service-product system (product oriented system, use an oriented and result oriented system) approaches determined a framework for the formation of a portfolio. This portfolio is including three types of e-learning business models. Examining the relevant characteristics, correspondence of behaviorism learning theory with a product-oriented approach, correspondence of cognitivism theory with a user-oriented approach and in finally match correspondence of constructivist learning theory with a results-oriented approach which is evident.

Conclusions - After reviewing the literature on the fields of e-learning, business model and product - service systems, we have achieved three types of e-learning business models. Then the variables in any of the business models were defined by using business model canvas tool and thus a portfolio consisting of three types of e-learning business model canvas was obtained.

Keywords: e-Learning, Business Model, Product-Service System.

JEL Classifications: I21, I23, I28, M19, O34.

\section{Introduction}

From September 2012, UK universities tuition and fee has increased to 9000 pounds per year. Many of those who do not have access to University turned to free online trainings provided by institutions such as MIT, Harvard and Stanford. Some people Like Christensen and Eyring (2011) believe that the business model of universities will change in the future. Udacity, EDX and Coursera with over millions of learners and more than 100 million dollars of budget are involved in e-learning industry (Lawton \& Katsomitros, 2012).

This paper presents a framework to determine a portfolio

* Master of Science, Management Information, Technology, Science and Research Branch, Islamic Azad University, Tehran, Iran. Tel: +98-21-4427-1861, E-mail: abbas.salehinejad@gmail.com

** Ph.D. Degree in Industrial Engineering by Tarbiat Modares University of Iran, Member of Al-Zahra University Academic Staff. Tel: +98-21-8861-5480-2, E-mail: rsamizadeh@gmail.com of e-learning industry business models. In the following, the research literature, including business models, e-learning, product-service system is reviewed.

\section{Literature Review}

\subsection{Business Model}

It seems that the executives, reporters, and analysts who used the term "business model" never really had a clear idea of what it meant (Osterwalder, 2004). There is no single definition for business models (Goethals, 2009; Seppanen \& Makinen, 2007). One of the reasons for the lack of single definition for business model is that every specialized field is trying to define the vocabularies from its view (Bieger \& Reinhold, 2011). Business model provide the logic necessary for how to create and obtain value for the stakeholders in the competitive environment of market 
(Casadesus-Masanell \& Ricart, 2010).

Kim and Im (2012) in their study by analyzing the data collected from two companies, one in the machinery industry and the other in the field of e-commerce, concluded that the company in the field of e-commerce and operate by the use of a variety of Internet-based service is more consistent with the framework proposed by Osterwalder (2005), i.e., business model canvas and also has better efficacy. In this study, the business model canvas framework has been used for e-learning according to the correspondence of e-learning with e-commerce and Internet-based services. Osterwalder and Pigneur (2010) defines business model as the logic of a company to create, deliver and acquire value. With the help of business model and customers, more interests and more satisfaction with the business are achieved. The business model canvas describes how 9 components of the business model correspond. These components are an effective way for drawing the pictures of how organization work. Osterwalder, Pigneur, and Tucci (2005) mentions the business model components in 9 separate variables in <Table 1$\rangle$.

<Table 1> Nine Business Model Building Blocks

(Osterwalder et al., 2005)

\begin{tabular}{|c|c|c|}
\hline Pillar & \begin{tabular}{|c|} 
Business \\
Model \\
BuildingBlock
\end{tabular} & Description \\
\hline Product & $\begin{array}{c}\text { Value } \\
\text { Proposition }\end{array}$ & $\begin{array}{l}\text { Gives an overall view of a company's } \\
\text { bundle of products and services. }\end{array}$ \\
\hline \multirow{3}{*}{$\begin{array}{l}\text { Customer } \\
\text { Interface }\end{array}$} & $\begin{array}{c}\text { Target } \\
\text { Customer }\end{array}$ & $\begin{array}{l}\text { Describes the segments of customers } \\
\text { a company wants to offer value to. }\end{array}$ \\
\hline & $\begin{array}{l}\text { Distribution } \\
\text { Channel }\end{array}$ & $\begin{array}{l}\text { Describes the various means of the } \\
\text { company to get in touch with its } \\
\text { customers. }\end{array}$ \\
\hline & Relationship & $\begin{array}{l}\text { Explains the kind of links a company } \\
\text { establishes between itself and its } \\
\text { different customer segments. }\end{array}$ \\
\hline \multirow{3}{*}{$\begin{array}{l}\text { Infrastructure } \\
\text { Management }\end{array}$} & \begin{tabular}{|c|} 
Value \\
Configuration
\end{tabular} & $\begin{array}{l}\text { Describes the arrangement of } \\
\text { activities and resources. }\end{array}$ \\
\hline & $\begin{array}{c}\text { Core } \\
\text { Competency }\end{array}$ & $\begin{array}{l}\text { Outlines the competencies necessary } \\
\text { to execute the company's business } \\
\text { model. }\end{array}$ \\
\hline & $\begin{array}{l}\text { Partner } \\
\text { Network }\end{array}$ & $\begin{array}{l}\text { Portrays the network of cooperative } \\
\text { agreements with other companies } \\
\text { necessary to efficiently offer and } \\
\text { commercialize value. }\end{array}$ \\
\hline \multirow{2}{*}{$\begin{array}{c}\text { Financial } \\
\text { Aspect }\end{array}$} & $\begin{array}{l}\text { Cost } \\
\text { Structure }\end{array}$ & $\begin{array}{l}\text { Sums up the monetary consequences } \\
\text { of the means employed in the } \\
\text { business model. }\end{array}$ \\
\hline & $\begin{array}{l}\text { Revenue } \\
\text { Model }\end{array}$ & $\begin{array}{l}\text { Describes the way a company makes } \\
\text { money through a variety of revenue } \\
\text { flows. }\end{array}$ \\
\hline
\end{tabular}

\section{2. e-Learning}

There are numerous definitions of e-learning. Reaction against this concept depends on the field of application and the user. As we move from face to face to virtual trainings, the more complete will be e-learning as mentioned, the most complete definition can be given on e-learning is to "provide educational content by electronic medias such as CD-ROM, Internet, Intranet, audio and video files, and other medias such as mobile" (Kaur \& Singh, 2011; Lee, Song, \& Park, 2009; Selim, 2007). In this study, the definition has been applied for e-learning in virtual university environment.

\subsection{Types of e-learning}

E-learning can be divided into several types with respect to the objective, implementation, inclusiveness, stakeholders, investors market, access, learning theories, being online, pedagogical principles, type of provider, and the level of using services (Allen \& Seaman, 2010; Jovanović, Gašević, \& Devedžić, 2006; Mergel, 1998; Selim, 2007)

There are three basic theories of learning, fundamental to the understanding of instructional design. These are: Behaviorism, Cognitive, and Social Constructivism (Mergel, 1998). Behaviorism, Cognitivism and Constructivism are three areas of learning theories used when discussing about the educational environment. About 100 years ago, learning theories with the principles of Behaviorism began, and then evolved in the context of Cognitivism theories and have been continued by the broad theory of Constructivism until now (Holmes \& Gardner, 2006).

Behaviorism, as a learning theory, measures how the mind responds to external events without focusing on the thought process happening concurrently (Roweton \& Skinner, 1979). The theory is helpful in explaining how we learn facts and other information that do not rely on prior knowledge (Ally, 2004). Behaviorism has its limitations while explaining certain social behaviors, especially when experience and memory were involved during the situation (Mergel, 1998). The cognitivism theory views learning as a process of acquiring and organizing knowledge through a special structure called schema in the human brain (Good \& Brophy, 1990). Reinforcement through practices plays a key role in improving there tension of knowledge (Mergel, 1998). This theory is used to understand how humans learn principles and processes by utilizing both short-term and long term memory (Ally, 2004).

Constructive theorists view learning as an active process of observing, interpreting, and constructing information into knowledge (Cooper, 1993; Wilson, 1997). Social constructivism places greater importance on understanding based on previous knowledge and collaboration to encourage active learning (Tynjälä, 1999). Research by Tynjälä (1999) found that students in a constructivist learning environment acquired more diversified knowledge than students under traditional learning. A similar study by Lovett, Meyer, and Thille (2008) found that, online statistics students learnt a full semester's worth of material in half as much time and performed as well or better than traditional students. The origin of constructivism school is cognitive psychology, developmental psychology and anthropology. Constructivists believe that learners must obtain 
their knowledge through interaction with the instructor as the presenter of content, interaction with the environment and outlining the underlying concept on which learning is taking place (Bruning, Schraw, \& Ronning, 1999).

\subsection{PSS}

Product service system (PSS), see <Figure 1>, is a combination of products and services for complete coverage of customer needs (Goedkoop, Van Halen, Te Riele, \& Rommens, 1999). Vargo and Lusch (2004) suggest that PSS makes the preparation of orders easier with focusing on the product and services provided. Transactions and relationships are important under PSS approach (Vargo \& Lusch, 2004). Tan (2010) states that the business model is a useful tool for identifying PSS, because its implementation requires a redefinition and recreation of new business models.

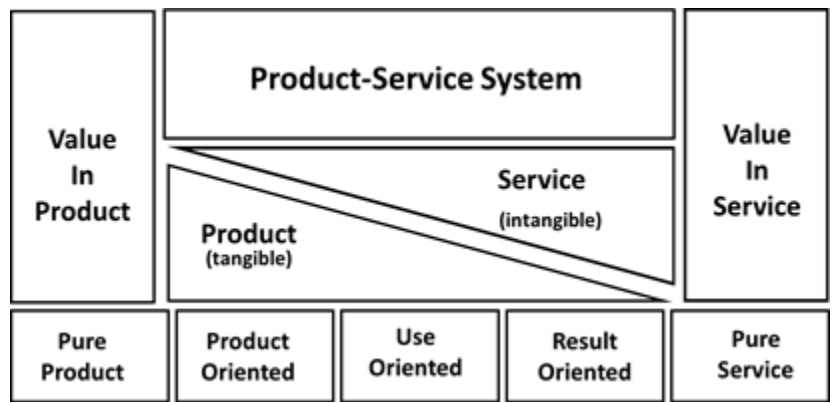

<Figure 1> Classification of PSS proposed (Tukker, 2004)

Since the value provided for the customer through services is faster than a value provided through products, implementation of PSS requires changing the practices of business and subsequently business model. Tukker (2004) proposes most accepted types of PSS widely used in scientific research literature. This category includes three types of PSS:

"Product- oriented services (POS), Use-oriented services (UOS) and Result-oriented services (ROU)". In Productoriented services (POS) method, customers are the product owner, while PSS providers offer the appropriate services and apply necessary changes for these services. After-sales service is an example of PSS services in this way offered to ensure the product application as well as strength and durability of the product. (Barquet, de Oliveira, Amigo, Cunha, \& Rozenfeld, 2013). In Use- oriented services (UOS), the product is owned by the manufacturer, and the retailer sells the use of product by leasing, renting or subscription. In this case, PSS maximizes the product life cycle and the possibility to reuse of raw materials. PSS prefers using high quality raw materials with long life to offer quality service and lasting services to keep the product in good condition for the provision of services and gaining interests (Barquet et al., 2013). Barquet et al. (2013) argue that manufacturers sell the result or the permission to use the product more than the product itself. In Result-oriented service (ROS), companies provide a set service and then PSS providers can benefit from their customers when necessary result was achieved through the product.

\subsection{Behaviorists as POS}

E-learning is a combination of educational contents which are the product aspects of PSS and a set of services reflecting the service aspect of PSS. Service dimension of e-learning can include full services that provide all operations related to e-learning to a limited part including software aspects of e-learning as a service. Thus, services in POS approach are the only context needed to provide educational content. The purpose of behaviorism school is to learn information and rules through testing, empiricism and obtaining clear results during the training process by testing and feedback. In contrast, product-oriented approach acts as advice and problem solving through the sale of the property (i.e., providing goods and services without having to meet the customer's desired results) along with some other services. <Table 2> shows the compatibility of behavioral learning theory with POS approach by the index of POS approach and using correspondence method.

<Table 2> Comparative approach behaviorism theory POS

\begin{tabular}{|c|l|l|l|}
\hline \multirow{4}{*}{$\begin{array}{c}\text { Behaviorism } \\
\text { School } \\
\text { Indicators }\end{array}$} & $\begin{array}{c}\text { Index } \\
\text { Behaviorism } \\
\text { school }\end{array}$ & POS \\
\cline { 2 - 4 } & Learn the facts & & \\
\cline { 2 - 4 } & Of teachers and students & & \\
\cline { 2 - 4 } & What training & & \\
\cline { 2 - 4 } & Problem with teacher & & \\
\cline { 2 - 4 } & Supported by teacher & & \\
\hline & Trial and error & & \\
\hline & Result on learning & & \\
\hline \multirow{4}{*}{$\begin{array}{c}\text { PoS } \\
\text { Indicators }\end{array}$} & $\begin{array}{l}\text { Consulting, questions and } \\
\text { test by teacher }\end{array}$ & & \\
\cline { 2 - 4 } & $\begin{array}{l}\text { Offer the course by } \\
\text { teacher to pupil }\end{array}$ & & \\
\cline { 2 - 4 } & Buy classroom & & \\
\hline
\end{tabular}

\subsection{Cognitivists as UOS}

If cognitivism approach is adopted in e-learning, i.e., the purpose of education is creating content in memory and using the ability of mind, we must reduce the direct content transfer and incorporate the value of service-orientation by providing various services, such as the services needed to measure the educational goals, services to measure the learners feedback, and obtaining feedback by the learner itself. Thus, the interest in the services is more prominent than educational products and this approach is consistent with UOS. <Table $3>$ shows the compatibility of behavioral learning theory with UOS approach by the index of UOS approach and using correspondence method. 
$<$ Table 3> Comparative study of cognitivism theory and UOS approach

\begin{tabular}{|c|l|l|l|}
\hline \multirow{4}{*}{$\begin{array}{c}\text { Cognitivist } \\
\text { School }\end{array}$} & Index & $\begin{array}{c}\text { Cognitivist } \\
\text { School }\end{array}$ & UOS \\
\cline { 2 - 4 } Indicators & Learning methods & & \\
\cline { 2 - 4 } & Memory utilization & & \\
\cline { 2 - 4 } & Learn how & & \\
\cline { 2 - 4 } & Supported by the process & & \\
\cline { 2 - 4 } & Teaching positions & & \\
\cline { 2 - 4 } & The use of meta-cognitive skills & & \\
\cline { 2 - 4 } & Training tailored to individual & & \\
\cline { 2 - 4 } UOS & Reaction committed, motivated & & \\
\hline \multirow{4}{*}{ Indicators } & Buy the right product & & \\
\cline { 2 - 4 } & Increase the product life cycle & & \\
\cline { 2 - 4 } & Use effective method of teaching & & \\
\cline { 2 - 4 } & Service to the average & & \\
\hline
\end{tabular}

\subsection{Constructivists as ROS}

Providing content in constructivism approach is not teaching by the instructor and learning by the learner, but also the learner in this approach pass through learning process using various co-educational tools in the e-learning space including virtual education technologies. If the relevant technologies are provided by service and basic service approach, then constructivism in e-learning is completely consistent with ROS. Learners in constructivism approach experience self-learning and self-education conditions by a variety of services of ROS e-learning. Some types of this services can be interactive services with other learners, services for reactions in the learners in the process of constructivism. The following table (<Table 4>) shows the compatibility of behavioral learning theory with ROS approach by the index of ROS approach and using correspondence method.

$<$ Table $4>$ Comparative study of constructivism theory and ROS approach

\begin{tabular}{|c|c|c|c|}
\hline \multirow{13}{*}{$\begin{array}{l}\text { Constructivism } \\
\text { School } \\
\text { Indicators }\end{array}$} & Index & $\begin{array}{c}\text { Constructivism } \\
\text { School }\end{array}$ & ROS \\
\hline & Interactive environment & & \\
\hline & Learning & & \\
\hline & Learn why the phenomenon & & \\
\hline & Your support & & \\
\hline & Teamwork & & \\
\hline & Group learning & & \\
\hline & Active learning situations & & \\
\hline & Learning & & \\
\hline & According to cognitive psychology & & \\
\hline & $\begin{array}{l}\text { Learning through interaction } \\
\text { with the environment }\end{array}$ & & \\
\hline & $\begin{array}{l}\text { Learning through knowledge } \\
\text { creation in mind }\end{array}$ & & \\
\hline & Learning over time & & \\
\hline \multirow{4}{*}{$\begin{array}{l}\text { ROS } \\
\text { Indicators }\end{array}$} & Maximum service & & \\
\hline & $\begin{array}{l}\text { Buy result of the educational } \\
\text { process }\end{array}$ & & \\
\hline & Maximum quality & & \\
\hline & The maximum response & & \\
\hline
\end{tabular}

\section{Materials and Methods}

This research is descriptive for the method it uses - it describes and interprets whatever that exists. It takes into account the existing conditions and relationships, prevalent thoughts, current processes, observable effects or progressive trends. Its outmost focus is on present, although it often reviews past events and effects related to the existing conditions. Library research was the base of data collection for this study (secondary data). According to the nature of research, it is a qualitative research that aims to provide a framework for identifying the best e-learning business model. Islamic Azad University e-campus was selected as a case study. At this stage of research, the presented model was to be considered for research purpose only. Because field study was not conducted for this research, proposal for pilot study (experimental) and extended study was not prepared.

\section{Results}

\subsection{How Is the Portfolio of e-Learning Business Models in the Target Population?}

The portfolio of e-learning business models in the target population consists of three business models for the following three components that 9 components of each are independently defined: "e-learning business model canvas with POS approach and behaviorism learning theory (BM1), e-learning business model canvas with UOS approach and cognitivism learning theory (BM2) and e-learning business model canvas with ROS approach and constructivism learning theory (BM3)."

\section{2. e-learning Business Model Canvas with POS Approach and Behaviorism Learning Theory(BM1)}

The correspondence of behaviorism theory and e-learning with POS approach was shown. In this section, 9 elements and components of the business model canvas are mentioned on this canvas that is called BM1. e-Learning in receptive manner, high volume of information provided by the teacher and e-learning system within limited time, learning based on the information provided by the teacher, learning by student, training with supervision, predetermined and clear training results, assessment tools by writing and oral questions, taking tests on predetermined dates according to the calendar, providing certain topics from specific and limited references during the training course, focusing on the presentation of the facts, learning routinely as an audience with certain objectives, severe content standardization.

Private and public educational institutions, students, pupils, universities as well as private learners are the audience of 
this business model. A variety of mentioned channels, including digital media such as optical compact discs; audio and video media such as radio and television; satellite channels, Internet and intranet; telecommunication networks such as mobile can be used with interactive or non-interactive approach. Distribution channel is available simultaneous, non-simultaneous or a combination of the above two.

Simultaneous and non-simultaneous relationship or a combination of the two cases are available by the use of e-learning tools including email, phone, video conferencing, mobile networks, social groups, forums. The cost structure is based on base cost method and activities are carried out in light of the minimal cost to provide e-learning services. The key activities range from the types of services that include almost all activities necessary for the preparation and presentation of educational content and providing various services related to delivering educational content.

Key sources can be existing resources owned by organization and external resources owned by others as well as a variety of human and physical resources such as Iranian and international public and private institutions, buildings, teachers, human resource, management, staff, network infrastructures and computer software and hardware, and also a variety of equipment used.

Key partners are divided into two main categories including knowledge partners and technology partners and also a variety of educational institutions, universities, research centers, industrial sector at home and abroad as well as the suppliers of network infrastructures and e-learning software and services offered and needed for e-learning. Based on the values provided and the type of applicant of value, revenue stream of this model includes: Certification and accreditation for institutions having the conditions to hold training course after qualification and receiving money for these certifications. Holding training courses in public and private companies and getting the costs. Registering free students and volunteers and getting registration fees. Concluding contracts with industry and business to train manpower required by the specific business and industry. The business model canvas called BM1 is shown in the <Figure 2>.

\section{3. e-Learning Business Model Canvas with UOS Approach and Cognitivism Learning Theory (BM2)}

The correspondence of cognitivist learning theory with UOS approach was shown. In this section, 9 elements and components of the business model canvas are mentioned on this canvas that is called BM2. The field of education in this e-learning model guide is formed by strengthening the learner to respond and using rapid feedback techniques of acquisition of knowledge. Learner-centered education is used rather than teacher-centered and a variety of teaching aids are provided in the course of training. Training is together with remote monitoring. Enabling and correct use of the ability of the mind and memory is the purpose of education.

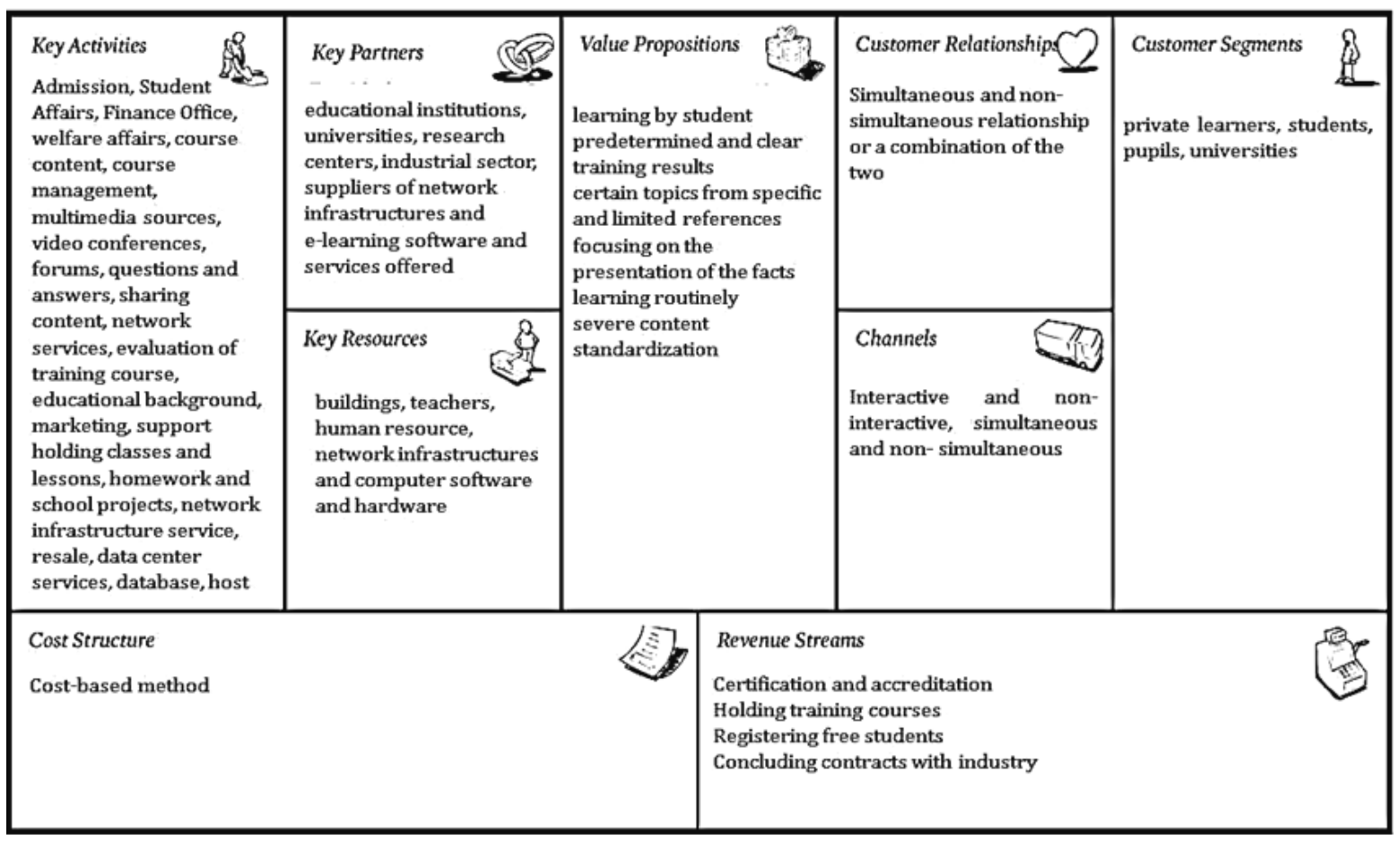

<Figure 2> e-learning business model canvas : BM1 
The ability to recover data from long-term memory is another value in this model. Information are provided in a classified way based on the principles of prevention from overflow in the memory. The content of the courses presented in the form of the application in real situations with the help of various tools such as simulations, scenarios, and game allows a variety of learning methods to be selected by the user based on preferences and interests. Learning process is different at each period and depends on a variety of environmental circumstances and so learning for teachers and students is performed in parallel. Emphasis on education quality rather than quantity and the widespread use of e-learning techniques and the lack of restrictions on school resources and also intelligent training process as well as independence to teacher in training are the values of this model.

With respect to the educational content and objectives, each education group can take advantage of this business model. Thus, variety of groups mentioned for BM1 are the audience of this business model as well. It should be noted that although this groups of customer are the same as BM1, the goals and values in each model is different. In addition to the customer groups mentioned, the employers looking for workers with certain records and consequently job seeker students are the customer groups of this model.

Distribution channels in this model should be interactive; therefore, all the digital channels with interactive feature which simultaneous and non-simultaneous or a combination of them such as intranets and the Internet, telecommunications networks, such as mobile phones have the necessary capability for simultaneous and non-simultaneous or a combination distribution channels. Simultaneous and nonsimultaneous relationship or a combination of the two cases are available by the use of e-learning tools including email, phone, video conferencing, mobile networks, social groups, forums.

In this business model, given the learning theory approach and based on cognitivist learning and also according to the type of educational content used in UOS approach and customer's goals, the cost structure is based on supply and demand and market research method.

Since all interactions and relationships, processes are performed by offering the products and other items related to the implementation of business model in e-learning with POS approach ranging from educational content as the product and offering educational content in the form of e-learning services, the key activities range from the types of services that include providing all services mentioned in BM1 model, employment, mobile content and services on mobile, customization, simulation, educational games, scenarios, as well as mobile services.

Considering the values provided and the kind of the applicant, the revenue stream of this model is the same as BM1 model that benefits from the revenue stream obtained from matching the students looking for job with employers need trained manpower and getting money for the introduction of appropriate human resources. Key resources and Key partners in this model are the same cases mentioned in the BM1. Business model canvas is shown in the <Figure $3>$.

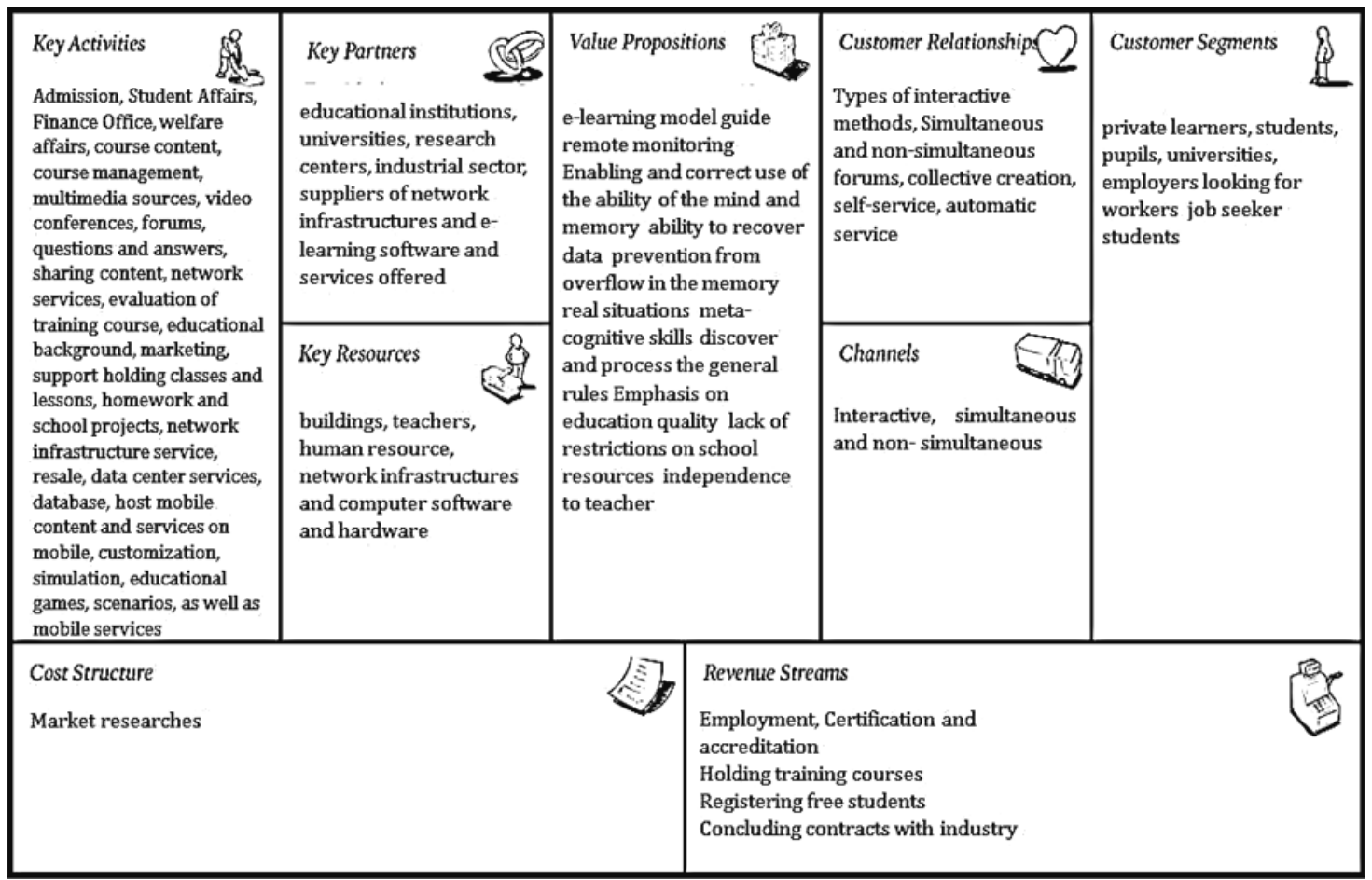

<Figure 3> Business model canvas of e-learning : BM2 


\section{4. e-Learning Business Model Canvas with ROS Approach and Constructivism Learning Theory(BM3)}

The correspondence of cognitivist learning theory with ROS approach was shown. In this section, 9 elements and components of the business model canvas are mentioned on this canvas that is called BM3. Approach in the training course is creating knowledge by each learner and understanding different issues including the real world of business and industry issues and also solving them during the training period. The training is done completely learner- centered and constructivist based on self-learning using the mind of each learner with regard to the individual differences. According to the group activities of each person, the necessary knowledge is obtained and learning in this model takes shape over time and starts to learn the reason for the phenomena. High level of learning thinking is made for dynamic environments and different environmental events occur in the situations, and thus self-support happens by the use of various tools and resources including educational games, scenario writing, simulation, problem solving and combined cases in online mode or in the network benefiting from individual abilities of each person considering the differences of individuals and complete adaptation of educational services with individual conditions and talent of each person. Maximum finding the talent of qualified personnel and motivating and dynamic learning both in the academic side of the learner side, as well as the maximum use of the e-learning industry with fully dynamic and free resources, and motivating highly in individuals and smart educational routines and independence from the teacher and training system are the values of this model.
With respect to the educational content and objectives of each educational group mentioned for BM1 and BM2 business models, the groups in this model have the goals and values that are different from the previous two models. In addition, the customers who want to rent e-learning infrastructure are also the customers of this model. It should be noted that this group was not present in the two previous models. The difference in gender and approach of the customers in this model with BM2 is in the increased level of learners' knowledge; meaning that this model has more adaptation for training higher education students, experts and elites rather than primary levels. However, even this approach is possible for low levels of education in conformity with the relevant criteria.

In this model, cost structure is based on a value-based approach; meaning that quality is of great importance and consequently, the highest prices compared to the two above models is offered.

Key activities mentioned in BM2 are also used in this model that activities related to the operationalization of services, including: customization, simulation, educational games, scenarios, mobile services (in an extensive and thorough form than BM2) are also done.

The Revenue streams of this model is the same as BM2, with the different that, given the values provided and the applicant presented by this model, renting the e-learning infrastructure is a revenue streams specific for this business model that was not in the previous models. Key resources, Key partners, Customer relationship and Distribution channels in this model, like BM2. The relevant business model is shown in the <Figure $4>$.

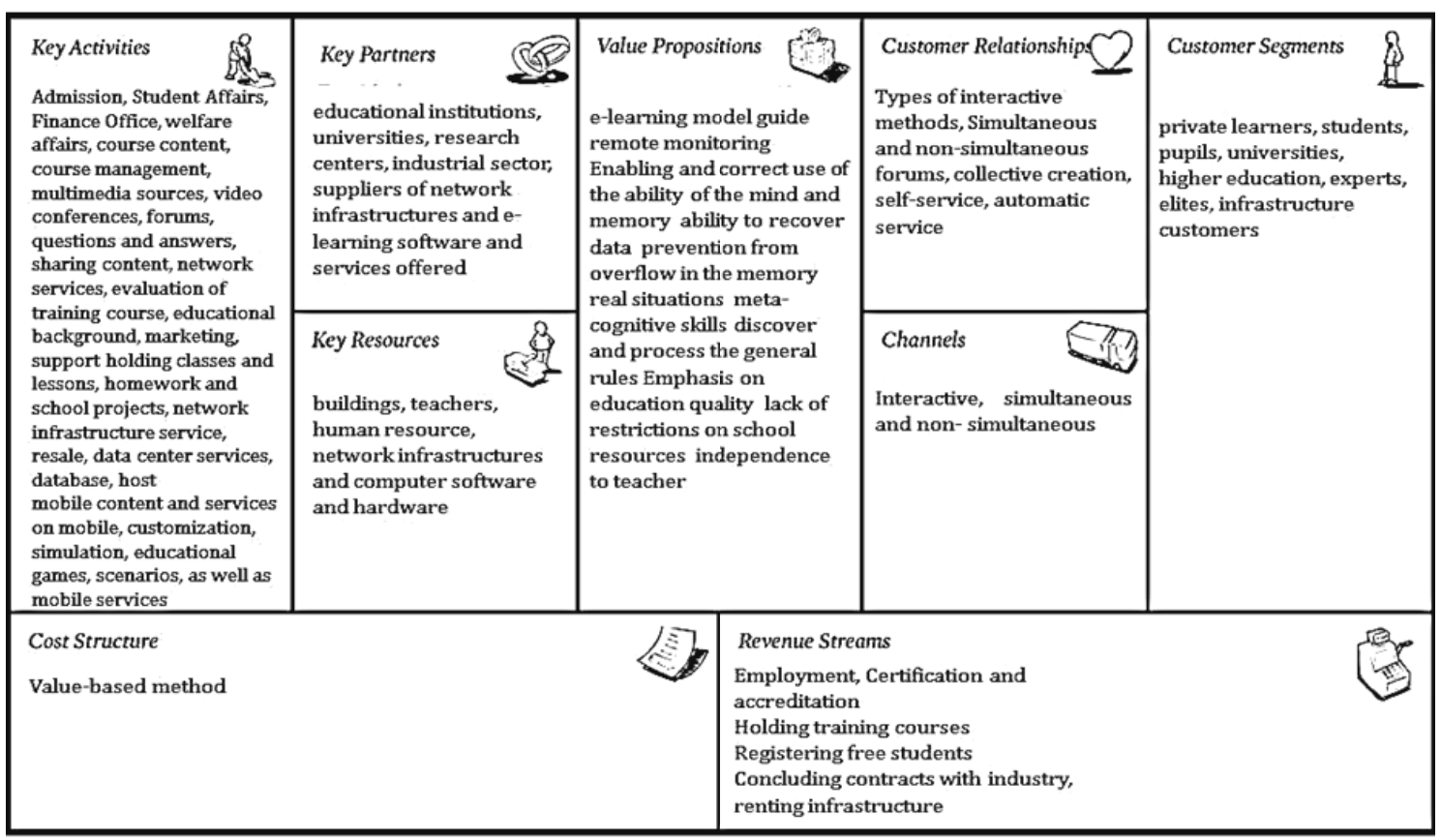

<Figure 4> Business model canvas of e-learning : BM3 


\section{Conclusion}

After reviewing the literature on the fields of e-learning, business model and product - service systems, by comparing three different approaches of service product systems with three different training and e-learning schools,

\section{References}

Allen, I. E., \& Seaman, J. (2010). Learning on demand: Online education in the United States, 2009. Sloan Consortium. PO Box 1238, Newburyport, MA 01950.

Ally, M. (2004). Foundations of educational theory for online learning. Theory and practice of Online Learning, 2, 15-44.

Barquet, A. P. B., De Oliveira, M. G., Amigo, C. R., Cunha, V. P., \& Rozenfeld, H. (2013). Employing the business model concept to support the adoption of product-service systems (PSS). Industrial Marketing Management, 42(5), 693-704.

Bieger, T., \& Reinhold, S. (2011). Das wertbasierte Geschäftsmodell-Ein aktualisierter Strukturierungsansatz. Innovative Geschäftsmodelle, 13-70.

Bruning, R. H., Schraw, G. J., \& Ronning, R. R. (1999). Cognitive psychology and instruction. Prentice-Hall, Inc., One Lake Street, Upper Saddle River, NJ 07458.

Casadesus-Masanell, R., \& Ricart, J. E. (2010). From strategy to business models and onto tactics. Long Range Planning, 43(2), 195-215.

Christensen, C. M., \& Eyring, H. J. (2011). The innovative university: Changing the DNA of higher education from the inside out. San Francisco: Jossey-Bass.

Cooper, P. A. (1993). Paradigm shifts in designed instruction: From behaviorism to cognitivism to constructivism. Educational technology, 33(5), 12-19.

Goedkoop, M. J., Van Halen, C. J., Te Riele, H., \& Rommens, P. J. (1999). Product service systems, ecological and economic basics. Report for Dutch Ministries of environment (VROM) and economic affairs (EZ), 36(1), 1-122.

Goethals, F. (2009). The unified business model framework. Little Economie \& Management, 9, 1-47.

Good, T. L., \& Brophy, J. E. (1990). Educational psychology: A realistic approach. White Plains, NY; Longman.

Holmes, B., \& Gardner, J. (2006). E-learning: Concepts and practic. California: Pine Forge Press.

Jovanović, J., Gašević, D., \& Devedžić, V. (2006). Dynamic assembly of personalized learning content we have achieved three types of e-learning business models. Then in the next step, the variables in any of the business models were defined by using business model canvas tool and thus a portfolio consisting of three types of e-learning business model canvas was obtained.

on the semantic web. In European Semantic Web Conference (pp.545-559). Springer Berlin Heidelberg.

Kaur, M., \& Singh, B. (2011). eLearning, eHealth and eBusiness in India. In Proceedings of International Conference on Computer Communication and Management (ICCCM 2011).

Kim, S., \& Im, K. H. (2012). Business model characterization by analyzing business model components of patent data. Applied Mathematics \& Information Sciences, 6(1), 303-309.

Lawton, W., \& Katsomitros, A. (2012). MOOCs and disruptive innovation: The challenge to HE business models. London: Observatory on Borderless Higher Education.

Lee, C., Song, B., \& Park, Y. (2009). Generation of new service concepts: A morphology analysis and genetic algorithm approach. Expert Systems with Applications, 36(10), 12454-12460.

Lovett, M., Meyer, O., \& Thille, C. (2008). JIME-The open learning initiative: Measuring the effectiveness of the OLI statistics course in accelerating student learning. Journal of Interactive Media in Education, 2008(1).

Mergel, B. (1998). Instructional design and learning theory. Retrieved January, 4, 2010.

Morris, M., Schindehutte, M., \& Allen, J. (2005). The entrepreneur's business model: Toward a unified perspective. Journal of Business Research, 58(6), 726-735.

Osterwalder, A., \& Pigneur, Y. (2010). Business model generation: $A$ handbook for visionaries, game changers, and challengers. John Wiley \& Sons.

Osterwalder, A., Pigneur, Y., \& Tucci, C. L. (2005). Clarifying business models: Origins, present, and future of the concept. Communications of the association for Information Systems, 16(1), 1.

Selim, H. M. (2007). Critical success factors for e-learning acceptance: Confirmatory factor models. Computers \& Education, 49(2), 396-413.

Seppanen, M., \& Makinen, S. (2007). Towards a classification of resources for the business model concept. International Journal of Management Concepts and Philosophy, 2(4), 389-404. 
Roweton, W. E. (1979). BF Skinner. Reflections on behaviorism and society. Englewood Cliffs, $\mathrm{NJ}$ : Prentice Hall.

Tan, A. R. (2010). Service-oriented product development strategies. DTU Management.

Tukker, A. (2004). Eight types of product-service system: Eight ways to sustainability? Experiences from SusProNet. Business strategy and the environment, 13(4), 246-260.
Tynjälä, P. (1999). Towards expert knowledge? A comparison between a constructivist and a traditional learning environment in the university. International journal of educational research, 31(5), 357-442.

Vargo, S. L., \& Lusch, R. F. (2004). Evolving to a new dominant logic for marketing. Journal of marketing, 68(1), 1-17.

Wilson, B. G. (1997). Reflections on constructivism and instructional design. Instructional development paradigms, 63-80. 